\title{
A Guerra dos Cem Anos e os projetos de Cruzada de Filipe de Mézières no Sonho do Velho Peregrino.
}

José Roberto de Almeida Mello

Departamento de História - FFLCH/USP

O Sonho do Velho Peregrino de Filipe de Mézières é, como outras tantas escritas na Idade Média, uma obra de caráter alegórico. Tal gênero era nessa época bastante apreciado, conquanto os trabalhos produzidos nem sempre seguissem os padröes literários da alegoria convencional. E este o caso do Sonho do Velho Peregrino, onde o autor não consegue sustentar continuadamente a alegoria, tratando os assuntos e os personagens ora no plano alegórico, ora no plano real.

Também o artifício literário que emprega para colocar suas alegorias em cena é bastante familiar aos conhecedores da literatura medieval: o sonho. Os exemplos desta técnica se multiplicam, bastando citar entre eles os do Somnium Viridarii, do Pearl, do Piers Plowman de Langland e o Vox Clamantis de Gower.

O frequiente uso de tal recursos pelos autores medievais tem sua explicação quer na mentalidade da época, quer nos hábitos literários, quer em questóes de ordem política. De um lado o sonho era uma das chaves de que o homem medieval dispunha para atingir o mundo oculto, a realidade sobrenatural. Presságios, verdades, avisos divinos, eram, quase sempre, recebidos através de sonhos (1). De outro, o sonho permitia estabelecer o cenário para a ficção literária, para a alegoria portanto, imprimindo logicidade e credibilidade naquilo que, em outro contexto, pareceria absurdo. Finalmente uma vez que se concebiam como verdadeiras as mensagens oníricas, os sonhos forneciam excelente camuflagem para a crítica pessoal e política, já pelo disfarce da metáfora e da alegoria, já por isentar o autor

(1) - Cf. Le Goff, J. La civilization de l'Occident Médiéval, Paris, Arthaud, 1967, Cap. IX, esp. pp. 420-21 Holdsworth, C. J. "Visions and visionaires in the Middle Ages." History, XLVIII, 163, 1963, pp. 141-153. 
da responsabilidade por suas afirmações. $\mathrm{E}$ isto era de grande valia numa época em que as garantias pessoais eram inexistentes ou mínimas; quando o simples murmúrio contra a pessoa do rei, ou de um poderoso, poderia custar a liberdade e até mesmo a vida do culpado (2).

Da mesma forma o motivo da viagem, que Filipe emprega para discorrer sobre o mundo cristão da época, encontra paralelos em outros trabalhos medievais de fôlego. Esse motivo não só contribuía para a conservação da unidade do trabalho, bem como permitia ao autor um amplo desenvolvimento do tema e uma boa exibição de seus enciclopédicos conhecimentos.

No caso do Sonho do Velho Peregrino ocorre ainda um fenômeno interessante: ele foi precedido por duas obras mais "realistas", o Livro do Jovem Peregrino e o Livro do Velho Peregrino (3). Ambas são continuamente mencionadas pelo autor no decorrer do Sonho, e pela maneira como o faz nos permite suspeitar que as três obras formariam uma espécie de sequiência biográfica da evolução de seus sentimentos e experiências espirituais. Embora escritas todas elas após seu recolhimento ao convento em 1380 , as duas primeiras corresponderiam psicologicamente aos seus anos de atividade no Oriente, enquanto a última, o Sonho, corresponderia ao seu estado de espírito após a reclusão.

Jovem Peregrino: nascido na Picardia, na aldeia de Mézières, em 1327, Filipe começou desde 1339 uma vida de andanças e viagens, que o levariam até o reino de Chipre. Aí obteve o cargo de chanceler que só abandonou em 1369, quando o seu rei, Pedro de Lusignan, foi assassinado. Retornando ao Ocidente entrou para o Conselho de Carlos V da França e, após sua morte, participou do conselho da regência. Somava assim aos seus conhecimentos da geografia e política do Oriente os da política do Ocidente. No entanto em 1380 deixou de lado as atividades políticas para

(2) - Stillwell, G. em seu artigo "John Gower and the last years of Edward III" (Studies in Philology, XLV, 1948, pp. 469-70), nos conta que o Chronicon Angliae não pode ser divulgado no reinado de Eduardo III no seu texto original dada a liberdade das críticas contra a corte. Estas foram também disfarçadas sob a capa da alegoria na anônima Profecia de Bridlington e no Mirour de l'Homme de Gower. Ver a propósito o Appendix B, "The Dangers of Political Comment in Fourteenth Century England", do livro de Barnie, J. War in Medieval Society. Londres, Weidenfeld \& Nicholson, 1974, pp. 142-45.

(3) - As obras que Filipe designa como Livro do Jovem Peregrino e Livro do Velho Peregrino são certamente a Peregrinação do Pobre Peregrino e a Pequena Peregrinação do Pobre Peregrino, ambas hoje perdidas. O Peregrino é obviamente o próprio autor, que na obra estudada "sonha" com a paz da Cristandade e a realização da cruzada. Sobre a produção literária de Mézières pode-se consultar o velho livro de Jorga, N. Philippe de Mézières, 1326-1405, et la croisade au XIVe siècle, 1986, e a introdução de Coopland, G. W. em sua edição do Sonho do Velho Peregrino, Cambridge University Press 1969, vol. 1. As qualidades literárias e possibilidades dramáticas desța obra são estudadas por Bell, Dora M. Etude sur le Songe du Vieil Pélerin de Philippe de Mézières (1327-1405), 1955. 
recolher-se ao convento dos Celestinos em Paris, onde permaneceu até a morte em 1405. E a esta fase de sua vida que o Sonho do Velho Peregrino corresponde psicologicamente. Cessadas as atividades, só lhe restava sonhar ccm a realização dos projetos de cruzada há muito acalentados. Mas era um sonho que não esquecia a realidade: mesmo do retiro ele continuava atento ao desenrolar dos acontecimentos deste mundo. $\mathrm{E}$ não se limitava a obter informações, continuava a aconselhar o jovem monarca francês e a tentar intervir no jogo político entre a França e a Inglaterra, como o demonstra sua Epístola ao Rei Ricardo II, de 1395. Aliás nos seus conselhos a Carlos VI transparece claramente a idéia que fazia de si como intermediário a serviço da Divina Providência. Ele conhecia certas visões sobre os reis da França e da Inglaterra, e as apresentara ao primeiro:

"... lesquelles visions par le moyen de l'apostole saint Jacques assez clerement a toy, jeune Moyse, Beau Filz, ont este presentees ou revelees, comme il est plus clerement contenu en l'espitre secrete de doulce ammonicion que le Vieil Pelerin nagaires en sa sellete presenta" (4).

O contato com viajantes e peregrinos no Oriente e a estadia em Chipre deram a Filipe o gosto pela cruzada, contribuindo para formar o ideal que nortearia sua vida e sua obra. Este já aparece completamente elaborado na Nova Religio Passionis Jhesu Christi, cuja primeira redação data de 1367.

Aliás, esse ideal não somente orientou-lhe os trabalhos, como também determinou-lhe as ocasiões para escrevê-los. A produção literária de Filipe segue de perto os sucessos da política entre os reinos cristãos do Ocidente. Quando esta se mostrava propícia à realização dos projetos de cruzada ele punha-se a escrever. Assim o Sonho do Velho Peregrino, terminado em fins de 1389 , é um produto direto das perspectivas de paz que se abriram nas relações franco-inglesas entre 1388-1389.

O enquadramento alegórico inicial da obra é dado pela parábola do homem rico que, estando para viajar, chamou três servidores e deu a cada um uma moeda, da qual the deveriam prestar contas quando de seu retorno. Dois a devolveram com lucro, o terceiro limitou-se a restituí-la, sendo por isso censurado (Mat. XXV, 14-30).

Esse tema é então desenvolvido através das moedas morais deixadas neste mundo por Cristo. A Rainha Verdade e suas auxiliares, Paz, Misericórdia e Justiça, viajam por todo o Ocidente Cristão verificando a qualidade das moedas de cada reino e, pois, suas possibilidades de participação na cruzada. Todavia, as andanças dessas ilustres senhoras esgotam-se já no primeiro livro. Os dois restantes, dos três que compõem a obra, se ocupam

(4) - Livro III, cap. 207 (vol. 2, p. 376). Para fins de citação seguimos a divisão em capítulos dada por Coopland na edição acima mencionada em dois volumes. Para facilitar a identificação damos entre parênteses o volume e a página. 
da França: um descreve a situação atual do reino, outro apresenta conselhos ao jovem Carlos VI sobre a condução do governo.

A razão de tal distribuição dos assuntos parece residir no fato de que Filipe via dois grandes empecilhos de ordem geral à realização da cruzada pelo soberano francês - ele seria seu chefe natural, só, ou juntamente com o rei da Inglaterra.

O primeiro, revelado na parte inicial da obra, era a situação política da Cristandade: o maior óbice no momento sendo o conflito entre a França e a Inglaterra (5). O segundo aparece nos dois livros restantes, com a descrição do reino francês e a indicação dos problemas que aí estavam a exigir uma solução imediata. Com longa experiência política, sabia o autor que dificilmente se entregaria com ardor ao santo empreendimento o soberano que deixasse atrás de si um reino em desordem.

As apreciaçōes sobre a Guera dos Cem Anos aparecem então no primeiro livro, principalmente nos quatro capítulos (76 a 79) que tratam da visita da Rainha Verdade à Inglaterra, e no terceiro, quando Filipe expõe a Carlos VI suas idéias acerca da paz (capítulos 270 a 272). No entanto, como o conflito franco-francês envolvia também a Península Ibérica, esta entra igualmente nas considerações do autor, num dos capítulos do primeiro livro.

A visão que Filipe nos apresenta da Guerra dos Cem Anos longe está de ser uma visão global, muito embora ele estivesse consciente de seu prolongamento cronológico e de suas ramificações políticas. Ela é montada a partir do objetivo que o levou a examinar a questão: a exequiibilidade de seu projeto cruzadístico. E esse mesmo objetivo criou então duas perspectivas de abordagem, condicionando e limitando a imagem da guerra no Sonho do Velho Peregrino.

Uma delas foi fornecida pelas auspiciosas tendências da política inglesa em 1389. Ricardo II conseguira superar as duas crises de $1386 \mathrm{e}$ 1388 e retomava então as rédeas do poder. Seu pendor para a paz e as démarches feitas nesse sentido desde 1386, com a participação de Leão $\mathrm{V}$ da Armênia, entusiasmaram o autor, levando-o a estudar e ponderar os fatores da política inglesa, suscetíveis ainda de entravar tão boas iniciativas (6).

(5) - No capítulo 284 do terceiro livro ele enumera trinta condições necessárias à preparação da cruzada, sendo a primeira a paz com a Inglaterra, (vol. 2, p. 231). Ver também I, 77 (vol.2, p. 399).

(6) - I, 78 (vol. 1, p. 400). A política pacifista de Ricardo e seu chanceler, Miguel de la Pole, fora interrompida duas vezes, em 1386 e 88, pelo triunfo da oposição aristocrática, liderada pelo duque de Gloucester e pelo conde de Arundel. Quanto às atividades de Leão $\mathrm{V}$ da Armênia, ele aparecera na corte francesa em 
A outra perspectiva foi criada pela idéia de que a guerra estava a cavar um abismo no seio da Cristandade num momento pouco oportuno, gerando uma infinidade de males materiais e espirituais.

Assim pois, no Sonho do Velho Peregrino, Filipe não está interessado diretamente na luta entre a França e a Inglaterra. Apenas um momento da mesma the chama a atenção, os anos finais da década dos oitenta. Se lança um olhar retrospectivo aos eventos passados, o faz meramente para apoiar seu ponto de vista sobre o presente. A extensão cronológica da guerra é assim introduzida quase acidentalmente. Ela serve para registrar a duração catastrófica e a permanência de algumas das suas causas.

Duas ordens de referências cronológicas são usadas: uma histórica, outra literária .Aquela é extrínseca ao plano alegórico, baseada nos eventos históricos, e faz remontar o início da guerra ao tempo de Eduardo III. Ela dura bem cinqüenta anos, como diz a Verdade aos filhos desse soberano:

"Pour vostre (et) male guerre, esmeuz par orgueil et ambicion pour ung trespou de terre, toute la Crestiente cinquante ans sans cesser a este bestournee...(7).

Nela se enquadram as lembranças das incursões de Eduardo na França e do embaraço que causaram aos projetos de cruzada de Filipe VI e Joãoo-Bom, e, em especial, as recordações dos terríveis episódios de Crécy e Poitiers (8).

De ordem literária é a menção ao "tempo do Velho Peregrino", que só poderia ser plenamente entendida pelo leitor das duas obras anteriores de Filipe, sobretudo o Livro do Venho Peregrino:

"Qui pourroit', dist la royne (a Verdade), 'nombrer les ames lesquelles au temps du Vieil Pelerin vous (os tios de Ricardo II) avez mande ou envoye en enfer depuis $L$ ans,... (9).

A referência aos cinquienta anos nos livra contudo da ignorância sobre o sentido da alusão. E, mais adiante, no capítulo 77 do mesmo livro, o autor é ainda mais preciso, identificando esse "tempo do Velho Peregrino" aos reinados de Filipe VI e João-o-Bom (10).

1384 buscando auxílio contra os turcos. Participou das negociações de paz com a Inglaterra entre 1385 e 1387 e esteve presente às conferências dos embaixadores franceses e ingleses em 1392 e 93, onde fez novamente apelos em prol da cruzada. Ver Palmer, J. N. N. England, France and Christendom. Londres, Routledge \& Kegan Paul. pp. $25,68,84-5,190$ e passim.

(7) - I, 76 (vol. 1, p. 397). Cf. também I, 75 (idem, pp. 394-6), 77 (idem, p. 399) e III, 270 (vol. 2, p. 374).

(8) - Idem (nota anterior) e I, 76 (vol. 1, p. 378) para a menção das batalhas de Crécy e Poitiers.

(9) - I, 76 (vol. 1, p. 396).

(10) - I, 77 (vol. 1, p. 399). 
Qualquer um dos sistemas cronológicos que se adote, ele está sempre relacionado ao aspecto calamitoso da guerra, contribuindo para enfatizá-1o ao notar sua duração. Porque a guerra era uma catástrofe, tanto pelos dnos materiais, quanto pelos danos morais e espirituais que provocava entre a Cristandade.

Danos materiais. As maiores vítimas eram a França e seus aliados ocasionais, Escócia e Castela. Ao derramamento de sangue "humano e cristão" somava-se a seqüela de males que habitualmente enchem as páginas das crônicas contemporâneas: um número de órfãos e viuvas, de mulheres violentadas, de pessoas mutiladas, de igrejas destruídas, de pilhagens e extorsões reduzindo as populações à miséria (11).

Danos morais e espirituais. Era a Cristandade toda a sofrer. A matanças, nos combates e fora deles, traziam repentinamente a morte a pessoas despreparadas para enfrentá-la, causando a perda de muitas almas e ganhos consideráveis para o inferno (12). Pior ainda: a luta expandira-se pelo Ocidente, com o tomarem uns partido dos ingleses, outros partido dos franceses, e, destarte, todos consentiam na efusão de sangue cristão (13). $\mathrm{E}$, o mais grave de todos os males, a guerra vinha atrapalhando os planos para a libertação do Santo Sepulcro. Por duas vezes, no "tempo do Velho Peregrino", os reis da França tentaram partir para Jerusalém, sendo impedidos pelos ingleses (14).

De fato, Filipe de Valois tomara a cruz em 1329 e começara a preparar-se para a cruzada, reunindo uma frota no Mediterrâneo. Mas, em 1335, o papa Bento XII, alarmado com o andamento da política angloescocesa e com a crescente tensão entre Eduardo e Filipe, suspendeu tais preparativos. Este então transferiu a frota para a Mancha, assustando os ingleses e favorecendo assim o desencadeamento das hostilidades em 1337. Seu filho, João, tomou a si mais tarde, em 1362, a responsabilidade pelo cumprimento do voto paterno. Mas, viu-se também impossibilitado de cumpri-lo (15).

(11) I, 76 (vol. 1, pp. 396 e 98) e III, 270 (vol. 2, p. 374).

(12) I, 76 (vol. 1, pp. 394 e 96), 77 (id., p. 399).11

(13) I, 76 (vol. 1, p. 397). Embora o autor, como outros, condenasse em geral a efusão de sangue, tratando-se de sangue cristão isso era sumamente abominável, por descobrir o caráter fratricida da guerra.

(14) - I, 77 (vol. 1, p. 399).

(15) - Os projetos de cruzada de Filipe VI foram interpretados na Inglaterra como astuciosa manobra política. A proposta de uma cruzada conjunta com Eduardo III foi vista como uma tentativa de desviar a atenção deste monarca de suas sinistras intenções sobre a Inglaterra. A transferência da frota que reunira no Mediterrâneo para a Mancha confirmou tais impressões. Temos um exemplo disso num poema sobre a morte de Eduardo III publicado por Wright Th. nos Political Poems and Songs (Rolls Series), Londres, 1859, vol. I, p. 221.

Os propósitos de João-o-Bom relativos à cruzada parecem não ter sido totalmente isentos de cálculo político. Estando em embaraços com o adversátio, dada sua 
De Mézières tinha portanto razão em ver na guerra um real empecilho à cruzada, ainda mais que ela ameaçava eternizar-se. Os fatores que a desencadearam continuavam agindo, tornando necessária, antes de tudo, sua eliminação.

Ao analisar as causas gerais da luta ele não se afasta, contudo, das idéias comuns a outros escritores contemporâneos. A causa primordial eram os muitos pecados de franceses, escoceses e espanhóis, que atrairam o castigo divino na forma dos exércitos inglèses. Como explica a Verdade aos tios de Ricardo II:

"Le benoist filz de Dieu mon Pere, comme il feit des Gebusees, Chananees et Feresees a son peuple d'Israel, vous avoit ordonne ses sergens pour chastier son peuple, les Escoz et Francois pour leur pechiez" (16).

Entre os escoceses o principal pecado era a ingratidão. Não tendo reconhecido em tempo o castigo que lhes enviara Deus, através dos ingleses, continuaram ainda a sofrer a guerra e muitas outras tribulações (17).

Castela, devido às passadas faltas do povo, fora visitada por três duros castigos: a doença do rei João, a guerra com Portugal e o fracasso de Aljubarrota, os exércitos de João de Gaunt, duque de Lancaster. As causas das punições, principalmente da última, levam-nos um pouco atrás no tempo e são explicadas pelo próprio Filipe de Mézières, no capítulo 71 do primeiro livro. Ele abomina a memória de Pedro-o-Cruel, não pelos seus crimes ou pelo seu tirânico governo, mas por ter sido um traidor da fé cristã. Podia ter conquistado o reino de Granada para o Cristianismo, mas não o fez. Assim Deus vingou-se fazendo-o expulsar pelo irmão, o bastardo Henrique de Transtâmara, e deserdando suas filhas (18).

captura na batalha de Poitiers, e libertado sob juramento para levantar o dinheiro do resgate, a cruzada poderia ter sido um meio de tangenciar tais dificuldades. Mas a fuga de um dos reféns deixados em seu lugar obrigou-o a retornar ao cativeiro logo em 1363, para cumprir a palavra empenhada, impedindo-o de cumprir seu voto de cruzada.

$\mathrm{Na}$ realidade, porém, a cruzada planejada em fins do verão de 1362, e que também serviria para livrar o reino das companhias de mercenários, foi esquecida ainda nesse mesmo ano, segundo Coville, A. Les premiers Valois et la Guerre de Cent Ans, t. IV, vol. 1, da col. "Histoire de France", Paris, 1902, p. 166.

(16) - I, 76 (vol. 1, p. 398).

(17) - I, 80 (vol. 1, p. 403).

(18) I, 71 (vol. 1, pp. 385-87). O episódio mencionado foi o assassinato do rei de Granada, o rei Vermelho, ordenado por Pedro-o-Cruel, durante a estadia daquele em sua corte em busca de auxílio. Mézières atribui o crime à cobiça, já que o rei Vermelho trouxera consigo um belo tesouro. Pedro poderia ter aproveitado o ensejo para converter o infiel e o seu povo; mas não o fez, preferindo deitar as mãos no ouro que ele trouxera. 
Os quatro reinos envolvidos na contenda têm, portanto, seus destinos ligados através dos desígnios da Divina Providência.

No entanto, os defeitos inerentes à natureza humana provocaram o agravamento e $\mathrm{o}$ prolongamento dos castigos. $\mathrm{E}$ isto, parece, não estava entre os planos divinos! Os ingleses, especialmente os filhos de Eduardo III, foram além das incumbências que lhes foram confiadas. Não se contentaram com as belas vitórias, nem com resgates, nem com pilhagens. Levados pelo orgulho e pela cobiça, apossaram-se das terras dos franceses e escoceses, ignorando serem simples instrumentos de Deus. Atribuíram a si as vitórias por Ele concedidas, imbuídos que estavam das vãs doutrinas cavaleirescas e animados com os exemplos de um Gauvain e de um Lancelot. "... les victoires dessusdictes, par mon Pere a vous octroyes, vous avez actribuees a vostre vaillance et chevalerie, censura-os a Verdade (19).

Deparando com as estrondosas derrotas francesas e conquistas inglesas na primeira parte da guerra, Filipe encontrou uma saída honrosa para os vencidos nos desmandos, muito humanos, dos agentes da Providência. Entretanto, no caso das conquistas ele viu-se num impasse, que não conseguiu solucionar sem contradição. Se Deus controlava a luta e não planejava entregar o reino francês ao adversário (admití-lo seria, de certa forma, concordar com a justiça da causa do rei da Inglaterra), como permitira então tais conquistas? e, mais ainda, como explicar a conservação de muitas delas nas mãos dos ingleses?

Para tanto ele serve-se mais uma vez do argumento do castigo divino. As contínuas perdas dos ingleses após 1360 vinham a demonstrar que, realmente, as conquistas foram feitas contra a vontade divina. $O$ resíduo territorial ainda em seu poder revelava que a punição não havia sido suficiente para os franceses:

"Et ce tant peu que vous en tenez, est seulement non pas pour legitime possession mais pource que lesdiz royaumes (França e Escócia), bien batuz par vostre verge, ne sont pas encore bien chastiez" (20).

Aliás, a Inglaterra também estava, e continuaria, sendo punida por tais desmandos. A Rainha Verdade por intermédio de sua irmã Bonne Adventure (camareira da Justiça) deixava quatro meirinhos para aplicar tal correção ao reino: a Sedição, a Ignorância, a Suspeita e a Divisão dos Três Estados (21). Considerando-se que o Sonho do Velho Peregrino foi escrito em 1389 e o costume dos vates medievais de fazer previsões com base em eventos passados, podemos tomar os quatro meirinhos por uma alusão aos males que a Inglaterra vinha sofrendo há cerca de dez anos. Sedição certamente diz respeito aos movimentos aristocráticos de 1386 e 88; Ignorância talvez se relacione com a expansão das doutrinas heréticas de Wyclif

(19) - I, 76 (vol. 1, p. 397).

(20) - Idem (vol. 1, p. 398). 
e dos Lollards; Suspeita é uma alusão ao clima de intriga e discórdia na corte, e Divisão dos Três Estados o é às agitações em geral, desde a revolta campesina de 1381.

Então, para justificar mais cabalmente sua teoria sobre os agentes da Divina Providência e, igualmente, para verificar as condições morais do reino inglês para a cruzada, viu-se o autor na contingência de fazer uma completa análise da situação política do mesmo. O fato de gastar nisso quatro capítulos, contra um, e no máximo dois, que emprega para outros reinos, é bastante significativo.

Mézières fazia uma opinião nada lisonjeira do reino inglês, que ele designa simbolicamente como "la Nef Malvoisine et Creuse. As alquimistas da Rainha Verdade descobriram que as moedas inglesas, o noble e o esterterlino, tinham o brilho empanado pelos fatores morais negativos reinantes na ilha, sobretudo o orgulho. O reino havia conhecido dias melhores na época de Santo Anselmo e do Venerável Beda. Os elementos de referência que ele apresenta valem apenas como recordaçõs de um passado ideal e distante, quando governaram os não menos santos Osvaldo, Osvy e Eduardo o Confessor.

Reino pobre (nisso ele tinha razão: quanto à riqueza a Inglaterra fazia uma triste figura ao lado da França) com um povo orgulhoso, não gostando de ser repreendido por suas faltas. Porém, sua crítica é mais dirigida contra o clero, cavaleiros e homens de arma em geral, porquanto nos dá a entender que os comuns, especialmente os "bons comerciantes" não estavam tão voltados para a guerra.

Aos prelados é destinado todo um capítulo. A Verdade, dirigindo-se a eles, diz ser concebível se deixassem os cavaleiros levar por desejos de proeza e conquista; mas não se entendia como pastores de almas perturbassem a paz com o promover a guerra. Menciona em particular dois bispos: um era chanceler e outro conselheiro. Aquele tendo grande ascendência sobre os príncipes, o segundo sempre pronto para pegar em armas, tanto para defesa como para o ataque aos cristãos (22).

As invectivas são ineqüivocamente dirigidas contra Tomás Arundel, bispo de Ely, irmão do conde de Arundel, e Hugo Despenser, bispo de Norwich. Arundel foi designado chanceler em outubro de 1386 pelos Appellants, conservando o posto até a retomada do poder por Ricardo em maio de 1389. Mais tarde ele voltou a assumir essa função, mas Mézières se refere obviamente ao período de 86 a 89 . Quanto ao bispo de Norwich, sua vocação mais militar que religiosa tornou-o famoso. Após certas aventuras na década dos sessenta, ficou bastante conhecido pela célebre cruzada na Flandres em 1383 contra os partidários de Clemente VII. Todavia isso não foi o bastante. Em 1385 tomou parte na expedição de Ricardo

(21) - I, 78 (vol. 1, p. 401).

(22) I. 79 (vol. 1, p. 402). 
à Escócia e acompanhou o conde de Arundel em sua sortida naval contra a costa flamenga em 1386-87. É este último feito que Filipe parecia ter em mente ao mencioná-lo. Em 1388 entrou para o conselho real, após o impeachment de Simão Burley no Merciless Parliament (23).

Particularizando a acusação de promotores da guerra aos dois bispos, o autor isenta automaticamente a totalidade do clero inglês de culpa nessa política agressiva. O bispo de Norwich é um caso de inclinação pessoal para as atividades militares. Sua atuação no conselho real deve ter sido limitada, não só pelo tempo em que lá permaneceu, bem como pelo rumo pacifista que tomou a política externa do mesmo em fins de 88. Já Arundel e outros prelados participantes do conselho representam antes a facção política liderada por seu irmão e pelo duque de Gloucester que as tendências gerais do clero. É verdade que este sob Eduardo III, mormente nas décadas dos quarenta e cinqüenta, fora um ativo instrumento de propaganda, estimulando a população a aceitar a justiça de causa de seu rei contra o Valois usurpador. No entanto, sob Ricardo, as opiniōes se achavam tão divididas, que seria impossível atribuir a todo o clero insular, e mesmo aos prelados, propósitos belicosos. O que Mézières parece reprovar é, na realidade, a indiferença daquele clero em relação ao conflito. Assim ele cita - exemplo dos antigos bispos, verdadeiros delegados da Providência, qui desconseilloient la guerre et pourchassoient la paix en France et em Angleterre.

Os maiores responsáveis pelo prosseguimento das lutas eram então os cavaleiros, conduzidos tanto pelos maus exemplos dos romances, quanto pela exagerada crença em profecias "supersticiosas e apócrifas" (24). Mesmo assim, nem todos favoreciam o conflito; muitos não ousavam externar suas reais opiniões:

"Vray est que entre les chevaliers plusieurs en y avoit ausquelx guerre desplaisoit, mais pour les Noirs Sangliers et ung conte d'Arondel ilz n'osoient dire mot ne soustenir leur roy, ne les bons marchans ausst du royaume". (25).

Chegando em Londres a Verdade e sua corte se reunem com Ricardo e seus súditos numa grande igreja. A cena toda é descrita de forma assaz

(23) - Cf. os respectivos verbetes do Dictionnary of National Biography.

(24) - Realmente, tanto do lado francês como do inglês, corriam profecias, calcadas nos ditos de Merlim ou nos Oráculos Sibilinos, além de outros, acerca dos sucessos futuros dos respectivos soberanos. Elas são mencionadas, na Inglaterra, por Lourenço Minot e pela chamada Profecia de Bridlington, atribuida a João Erghome. $O$ apego dos ingleses do final da Idade Média a profecias parece ter sido proverbial. Cf. a respeito Taylor, R. The Political Prophecy in England. N. Y., Columbia University Press, 1911, esp. pp. 84-5. Num plano mais geral temos o livro de Reeves, M. The Influence of Prophecy in the Later Middle Ages. Oxford, Clarendon Press, 1969.

(25) - I, 79 (vol. 1, pp. 402-3). 
signfiicativa. À direita da Verdade sentava-se o clero e à esquerda os laicos, barões, burgueses e comuns, tendo ao centro o Jovem Javali Branco, Ricardo II, e:

“.. assez pres du Blanc Sanglier couronne estoient en piez plusieurs grans Sangliers, noirs et hericez, qui jadiz furent filz du puissant et noir Sangler, qui tant de foys par la divine permission rompy les hayes des belles vignes du grant champ a fleurs de lis dorees" (26).

O contraste não poderia ser melhor: o pequeno Javali Branco rodeado pelos grandes e sinistros Javalis Negros, seus tios, os duques de Lancaster, Gloucester e York. $\mathrm{O}$ autor consegue assim um sombrio efeito com o símbolo adotado para representar os membros da casa real da Inglaterra, o javali. Linhas adiante eles são novamente mencionados como os grans Sangliers Noirs parez des liepars, qui avoient les grans dens ressorlees et toutes rouges $d u$ sang des crestiens. O javali e o leopardo, este apenas como complemento, são os únicos símbolos empregados paar designar os reis e príncipes da Inglaterra, contrastando com a variedade usada para os reis da França.

Os leopardos heráldicos da casa real da Inglaterra são bem conhecidos, dispensando destarte maiores comentários. Quanto ao javali, sua utilização tem uma longa história literária. Como animal de grande ferocidade e bravura prestou-se sempre para a caracterização de personagens que se queriam dotados de tais qualidades. Assim, já nas profecias atribuídas a Merlim ele simboliza várias vezes Artur (o Javali da Cornualha) ou outros guerreiros e, uma vez, Henrique II, na profecia do Merlim Ambrósio relativa aos Sete Reis (27). Em algumas outras, provavelmente do século XIV, e também em poemas políticos da época, Eduardo III aparece por vezes como Javali. No vaticínio Os Seis Reis que Sucederão ao Rei João aquele soberano é, ora o Leão, ora o "Javali da Prosperidade, Nobreza e Sabedoria" (28). Num poema intitulado S. Tomás de Cantuária, escrito possivelmente após a batalha de Poitiers, Becket prevê que dois Javalis, Eduardo II e seu filho o Príncipe Negro, virão da nglaterra conquistar o reino da França e expulsar Filipe de Valois (29). Um dos javalis nascerá de sangue inglês e francês, (Eduardo III era filho de Isabela de França com Eduardo II), e não terá rivais no mundo. E, numa Invectiva contra a França, da mesma época, Eduardo aparece como o javali com presas brancas e agudas (30). Além do mais, o autor do Political Prophecy in England, de onde extraímos tais informações, acredita que uma das profecias de

(26) - I, 76 (vol. 1, p. 395).

(27) - Taylor, op. cit., pp. 10,12,15-17, 45-46.

(28) - Aaylor, op. cit., pp. 49-50.

(29) - Taylor, op. cit., pp. 58-59.

(30) - Ed. por wright, Th. in Political Poems and Songs, I, p. 27. 
Merlim referentes ao Javali, e interpretada como um prognóstico da invasão inglesa, fosse corrente em Paris no final do século XIV (31).

No Sonho do Velho Peregrino essa tradicional imagem simbólica sofre uma distorção, sendo ressaltado antes o aspecto ameaçador e cruel do animal.

Sobre o primeiro dos Grandes Javalis, Eduardo III, o autor não tem muitas queixas a fazer. Ele fora o iniciador do conflito, é verdade, mas com o consentimento divino, para castigar os pecados dos franceses. Com seus filhos, todavia, se deu o contrário: a desmedida ambição deles prolongou a luta e disseminou a desgraça além dos limites previstos por Deus. Isso não sendo suficiente, estavam a impedir o jovem monarca de fazer a paz com os adversários.

João de Gaunt, duque de Lancaster, e Tomás de Woodstock, duque de Gloucester recebem especial atenção entre os três tios ainda vivos de Ricardo II. O primeiro ocupa um lugar à parte nas críticas de Mézières, dada sua atuação na Espanha e na Gasconha. É através dela que o autor estabelece a ligação dessas duas regiōes com o processo geral da guerra anglo-francesa.

O destaque de Gaunt é merecido, pois durante as três últimas décadas do século XIV foi ele a mais importante e poderosa figura da aristocracia e da política inglesas. Apesar disso os motivos e idéias que o nortearam, e mesmo sua atuação política, são ainda objeto de dúvidas.

Uma dessas ações um tanto enigmáticas foi justamente o seu casamento, em segundas núpcias, com Constância, filha de Pedro-o-Cruel da Espanha, e, com a morte deste, as querelas em que se envolveu para fazer valer os direitos de sua esposa ao trono de Castela (32). No Sonho sua intervenção aí aparece, tanto como um desígnio da Divina Providência, tanto como um saldo negativo do governo tirânico de Pedro. No capítulo que trata dessa intervenção seu nome não aparece, mas ele, sua mulher e filhas, e os soldados ingleses estão sempre presentes no símbolo das "relíquias do rei Pedro":

(31) - Taylor, op. cit., p. 91.

(32) - A aliança franco-castelhana sempre parecera aos ingleses tão ameaçadora para a segurança da Gasconha, quanto a aliança franco-escocesa para o reino inglês. Além do mais a pirataria espanhola dificultava a comunicação entre a Gasconha e a Inglaterra, e punha em risco mesmo o litoral desta. A intervenção do Príncipe Negro em 1637 na disputa entre Pedro e Cruel e o bastardo Henrique de Trastâmara, as alianças matrimoniais dos filhos de Eduardo III, João de Gaunt e Edmundo de Langley, com a casa real castelhana revelam o interesse do governo inglês em neutralizar tão incômodo adversário. No caso do $d$. de Lancaster intervieram, todavia, fatores pessoais, tornando assim mais difícil distinguir em suas ações ulteriores aquelas decorrentes da iniciativa particular das resultantes da política oficial. Também os seus reais propósitos sobre o trono castelhano deram margem a discussões. Alguns autores o julgam sinceramente interessado na herança de Pedro: Russell, J.R. por 
"Lesquelle reliques, l'espee au poing, te (a João, rei de Castela) furent presentees en Galice pour estre adorees de l'universite des Espaigneulx e toy confundre et chassier hors du royaume". (33).

Essa a interpretação de Filipe para o desembarque das tropas inglesas em Coruña em 1386. Mas, no momento em que redigia o livro, a questão já havia sido resolvida. Linhas adiante ele alude à maneira como a misericórdia livrou João de tais relíquias sem efusão de sangue. E é mesmo possível que o próprio símbolo das relíquias tenha ocorrido ao autor a partir de um episódio decorrente do acordo de paz entre as partes: o translado dos ossos do rei Pedro (34).

No ano seguinte ao do desembarque na Galícia Gaunt, tendo adoecido, retirou-se para Bayonne. Aí é alcançado pela Rainha Verdade que o admoesta por recusar-se, juntamente com os irmãos, a dar liberdade aos gascões.

Como vemos, o maior dos Javalis, o duque de Lancaster, estava pessoalmente engajado na política exterior da Inglaterra desde o final do reinado de seu pai. Também é o único dos Javalís Negros a ser especificamente citado por Mézières. No mais, as alusões vão sempre ao conjunto deles. Alusões que valem praticamente como uma acusação direta ao seu irmão, o d. de Gloucester, já que o terceiro dos Javalis, o d. de York, não teve uma ação destacada sob o reinado do sobrinho.

Para o autor, entretanto, os Javalis representavam o partido da guerra, que procurava impor ao soberano, por todos os meios, sua política belicosa. Aqui, em termos gerais, ele retrata muito bem a essência das manobras políticas na corte inglesa: o pacifismo de Ricardo, a emergência da oposição liderada por Gloucester e Arundel, desde 1385, resultando nas crises de 86 e 88, a ascensão do conselho em 87, imposto pelos Appellants (35).

exemplo, no English Intervention in Portugal and Spain, Oxford, Clarendon Press, 1955, pp. 173-5 e, sobretudo, 184-5. Outros acreditam que ele desejava apenas obter uma transação vantajosa para seus direitos: Palmer, op. cit., pp. 69-70.

(33) - I, 72 (vol. 1, p. 389).

(34) - O episódio é relatado por Froissart da seguinte maneira: a esposa do duque de Lancaster, Constância, ao levar suas filhas à Espanha (primavera de 1388) para casar uma delas com o filho de João de Castela, passou por Montiel, onde seu pai estava enterrado. Aí, fez desenterrar-lhe os ossos, levá-los e colocá-los em um caixão, que levou para Sevilha onde lhes propiciou as devidas exéquias (Crônicas, III, 150). O Sonho do Velho Peregrino não menciona o casamento e, sequer, o acordo de paz, pelo qual Gaunt e sua esposa renunciavam aos direitos sobre a herança castelhana. Mas, pelas alusọes que faz à vitória incruenta do rei João e à ação da Divina Providência, transtornando os propósitos dos príncipes neste mundo, podemos deduzir que ele tinha conhecimento do último, pelo menos.

(35) - Dizemos em termos gerais, porquanto Gaunt participou apenas durante algum tempo da oposição, entre 82 e 86 . Também não foi, provavelmente, um fanático advogado da política agressiva em relação à França. Sua atitude face a guerra foi muito influenciada por seus interesses na Península Ibérica. 
Os tios de Ricardo são duramente censurados por suas ambições, as motivadoras da permanência do conflito. Eles levaram alguns deles até a tentativa de impedir o sobrinho de governar (36). Fracassando tal intento, eles o cercearam de tal arte, que ficou impedido de 'forjar suas moedas na forja da Dame Allegresse" (37). Defensor ardente da dignidade e das prerrogativas reais, Mézières se escandaliza com a ação dos Javalis:

“... vous avez este si hardiz de reguler et restraindre la puissance ordonnee de vostre roy, et de mectre la main en Cristum domini..." (38)

As referências se fazem portanto ao período que se seguiu ao parlalamento de 1386. Os Lord Appellants haviam conseguido afastar os ministros régios e eleger um conselho para tutelar o soberano, impondo a continuação das hostilidades com a França. Essa política, contudo, dado o rumo geral dos acontecimentos e a inépcia dos próprios Appellants, só produziu desastres, interna e externamente. Destarte, o próprio conselho tratou de mudar a sua atuação em fins de 1388 , buscando as possíveis aberturas para a pacificação. Ricardo, sagazmente, deixou-o agir e entabular as negociações; mas, estando estas em vias de concretização, reassumiu ele as rédeas do governo, colhendo assim os méritos de tal iniciativa.

Os sucessos da política inglesa tiveram portanto um forte reflexo na obra de Filipe. Como já adiantamos, foram eles, em parte, que o encorajaram a escrevê-la em 1389.

Filipe via em Ricardo o instrumento de Deus para a paz. O javali que o simboliza é jovem e branco, em oposição aos Velhos e Negros Javalis, seus tios. Malgrado a ascendência, ele é bom e puro, abominando o derramamento de sangue cristão provocado pelo pai. Cumpria-se pois o provérbio: "une noire vache engendrera bien un blanc veau" (39). Porém, a cousa não se passou dessa exata maneira. Aqui novamente as idéias do

(36) - Boatos sobre as más intenções dos tios de Ricardo circularam várias vezes, envolvendo mormente o duque de Lancaster. Como terceiro filho de Eduardo III era o candidato mais forte à sucessão após a morte do Príncipe Negro, pois o segundo filho, Leonel duque de Clarence, havia falecido em 1368. Durante a menoridade e, mesmo após a coroação de Ricardo, acusavam-no, à boca pequena, de planejar descartar-se do sobrinho. Tais boatos foram um dos motivos da tensão em suas relações com a corte entre 1383 e 85 .

Após a vitória dos Appellants em Radcot Bridge, nov. de 87, foi a vez de Gloucester ver-se acusado de planejar a deposição do rei. Segundo a versão da Whalley Chronicle ele teria mesmo chegado a depô-lo nos dias imediatos à vitória. Cf. Tuck, A. Richard II and the English Nobility. Londres, Ed. Arnold, 1973, p. 119.

(37) - I, 77 (vol. 1, pp. 399-400). No capítulo anterior a Verdade lhes dirige esta reprovação: et vous qui gouvernez le jeune Blanc Sangler Couronne..." (id., p. 396).

(38) - I, 77 (vol. 1, p. 400).

(39) - I, 79 (vol. 1, p. 401) 
autor sobre a realeza: Ricardo nascera negro como o pai, mas a água do batismo e a unção sagrada em suas mãos o regeneraram, fazendo sua peliça negra branca e resplendente (40).

Que esses prognósticos se realizaram efetivamente, provam-no o fato de Ricardo ter ordenado a suspensão das hostilidades e ter-se ligado por grande amizade ao jovem soberano francês (41).

A paz no seio da Cristandade era o mais ardente desejo do Velho Peregrino: a simpatia recíproca dos dois reis prometia concretizá-la. Além do mais, eram ambos jovens e isso vinha reforçar aquela promessa.

A juventude era um ingrediente importante na imagem do soberano ideal na Idade Média. Ao topos do puer-senex, transmitido pela literatura clássica (42), o pensamento popular medieval acrescentava o do puerinnocens. O primeiro valorizava o jovem com um predicado que, de ordinário, the não pertencia, a sabedoria dos velhos. $\mathrm{O}$ segundo, porém, $\mathrm{O}$ celebrava justamente por não possuir a malícia e a astúcia dos adultos. A pureza de coração do jovem monarca opunham-se então as manhas maldosas de velhos ministros e conselheiros, que poderiam facilmente induzi-lo ao erro (43).

Daí a alegria de Filipe com a pouca idade de seus governantes, Ricardo contando vinte e dois e Carlos vinte e três anos em 1389. O simbolismo literário no Sonho traduz bem a ênfase dada a esse binômio da juventude-inocência: Ricardo é o "jovem Javali Branco" e Carlos, entre outros, é o "jeune Cerf Volant", o "branco Falcão Peregrino de bico e pés dourados", ou o "Jovem Moisés Coroado" (44). E também a pureza tinha um cunho especial neste caso, por serem ambos inocentes da matança de cristãos:

(40) - Id. (ibid.).

(41) - I, 77 (vol. 1, p. 399). Ricardo nutria realmente forte simpatia pelos franceses e por Carlos VI; tanto que foi por vezes criticado por essa francofilia. Mas o grande arquiteto da paz foi, no dizer de Palmer, o seu chanceler, Miguel de la Pole, acusado no parlamento de outubro de 1386. Ricardo teria sido conquistado por suas idéias. Palmer, op. cit., cp. 3.

(42) - Curtius, E. R. La littéreature européenne et le Moyen Âge Latin, Paris, 1956, pp. 122-25.

(43) - Vejam-se, por exemplo estes versos de uma canção contra as taxas, do reinado de Eduardo III, publicada por Aspins, I, nas Anglo Norman Political Songs, Oxford, Blackwell, 1953. O autor, após enumerar os impostos e os males que causavam diz:

Houme ne doit a roy retter talem pravitatem

Mes al maveis consiler per ferocitatem.

Le roy est jeovene bachiler, nec habet etatem

Nulle malice compasser set omnem probitatem.

Consilium tale dampnum confert generale. (11. 36-40).

Consultar também o artigo de Rosenthal, J. T. “The king's 'Wicked Advisers' and medieval baronial rebellions", Political Science Quarterly, LXXXII, 1967, pp. 595-618. 


\begin{abstract}
"...'Beau Filz, jeune Moyse Couronne' dist la royne Verite, 'il t'est demoustre que pource que jusque a ores par la bonte de Dieu tes mains n'ont point este souillees du sang de tes adversaires d'Angleterre, pource est il expedient pour la reformacion et nouvelle consolacion du royaume de Gaule que de ta part, Beau Filz, au roy d'Angleterre, innocent aussi $d u$ sang des Gallicans, tu lui doyes offrir bonne paix,..."

A juventude seria, no entanto, de pouco proveito, caso as duas coroas não estivessem interessadas em fazer as pazes. Do lado inglês, como já disemos, os Apellants, fracassada a política agressiva, procuravam por um paradeiro às hostilidades. Do lado francês, desde o término da guerra anglocastelhana em 1387, que o governo se mostrava disposto a escutar as propostas inglesas. Em abril desse ano Ricardo havia entrado em contato, mais uma vez, com o rei da Armênia e diversas embaixadas foram trocadas entre as duas cortes. Estavam a arranjar um encontro pessoal entre os dois reis n'algum ponto entre Calais e Boulogne, possivelmente para inícios de dezembro, segundo Palmer. Carlos deveria aguardar em Boulogne a chegada de seu colega inglês. Mas, durante a ida deste para Calais, a revolta armada dos Appellants e sua vitória em Radcot Bridge obrigaram-no a abandonar a projetada entrevista. Palmer entretanto não acredita numa interrupção definitiva, mas sim um adiamento apenas (46). Em 89 , com o poder de novo nas mãos, pode Ricardo retomar as negociações e conseguir em 18 de junho uma trégua com a França (47).

O Sonho do Velho Peregrino captou os ecos dessas démarches nas referências que faz ao desejo de paz do monarca inglês, às diligências de Leão da Armênia para consegui-la e à entrevista pessoal entre os governantes (48).

O autor temperava, no entanto, sua euforia com certos temores. Conhecendo a influência nefasta dos conselheiros ingleses, a casuística dos embaixadores e os interesses particulares envolvidos, ele sabia ser a paz não muito fácil de obter. $\mathrm{E}$ aqui até a juventude podia atuar negativamente. Carlos e Ricardo seriam facilmente enganados pela hipocrisia de seus servidores.

(44) - O simbolismo empregado para o rei da França é mais rico; porém os outros símbolos têm antes uma conotação mais patriótica e ligada à exaltação da monarquia francesa, como o "jardineiro do grande jardim das brancas flores douradas" (o lis das armas reais). A figura do "cerf volant" (o cervo correndo) faz também parte do acervo comum dos símbolos reais. Aparece com certa freqüência entre as alegorias preparadas no século XV para a recepção dos monarcas franceses, quando de suas entradas solenes nas cidades do reino. Cf. Guenée, B. e Léhoux, F. Les entrées royales françaises. Paris, C.N.R.S., 1968, pp. 73, 132-33, 135.

(45) III, 270 (vol. 2, pp. 373-4).

(46) - Palmer, op. cit., cp. VI.

(47) - Palmer, op. cit., p. 142.

(48) - I, 78 (vol. 1, p. 400) e III, 270 (vol. 2, p. 376). 
Conselheiros, advogados e prelados podiam ser muito rigorosos nas exigências e minuciosos na interpretação de pontos legais relativos aos direitos de suas Coroas. Experiências anteriores mostravam que as negociações sempre começavam auspiciosamente, num tom humilde. Mas, as discussões engajadas, levantavam então os delegados vários obstáculos, em nome da equiidade e de um implacável logicismo judiciário (49). A isso tudo somavam-se ainda os interesses pessoais dos capitães-de-guerra, que o autor coloca entre os piores adversários da paz:

"Et vous" observa aos soberanos, "gardez bien tous deux en traitant de la paix de trop croire a aucuns chevetaines, qui sont ou ont este nourriz et enrichez en la guerre, comme les loyres en l'estang" (50)

Prejudicados com a cessação dos combates eles seriam, contudo, os primeiros a auxiliar o rei nas proposições de paz. Maś, acobertados pela aparência de lealdade e da eqüidade, teriam sempre de reserva argumentos, à primeira vista sólidos, para romper as negociações.

Realmente a guerra se transformara numa indústria para soldados, pequenos capitães e senhores da nobreza, cujos soldos eram acrescidos com pilhagens e resgates. Mesmo um Arundel ou um Gloucester não ficavam imunes a tais estímulos (51).

$\mathrm{O}$ remédio contra isso seria um encontro pessoal dos dois jovens coroados, num lugar conveniente na fronteira do reino da França, onde pudessem, com poucos conselheiros de confiança, tratar livremente da paz. Filipe parecia depositar grande confiança nos conselhos e nas visões que transmitira a Carlos VI (52). Ele esperava que, nessa entrevista, este os comunicasse ao monarca inglês. Além do mais ele os exorta a abandonar o orgulho e a avareza, e se disporem para perdoar mutuamente as passadas ofensas.

Infelizmente, isso tudo não era ainda o bastante. Homem prático, Mézières sabia da existência de problemas que transcendiam a simples boa vontade dos rapazes. Problemas jurídicos, velhos de mais de cem anos, aos quais nem ele próprio é capaz de encontrar solução adequada.

O bom senso era uma saída. Para tanto ele evoca os horrores pretéritos... e futuros, se a guerra continuasse. E, neste caso, ou ter-se-ia a vitória de uma das partes, ou ambas seriam aniquiladas totalmente. Ante tão aterradora possibilidade não haveria certamente cavaleiro, na França

(49) - III, 270 (vol. 2, p. 375).

((50) $-I d$. ib.

(51) - Sobre o assunto ver Contamine, Ph. Guerre, état et société à la fin du Moyen Age. Paris, Mouton, 1972; Hewitt, H.J. The organization of war under Edward III, Manchester University Press, $1966 \mathrm{e}$ artigos in Fowler, K. (org.) The Hundred Years War, Londres, Macmillan Press, 1971).

(52) - Ver citação anterior à p. (2). 
e na Inglaterra, que não depusesse o orgulho e a ambição e se contentasse com somente a satisfação de seus direitos. O primeiro passo portanto seria renunciar à cobiça, evitando um rigor extremado nos termos dos acordos: "tu ne teignes pas les termes de rigueur maicte plainement", aconselha Filipe a Carlos VI (53). Também seria mister observar fielmente aquilo que viesse a ser estipulado.

Mas o rei poderia ser igualmente generoso em sua proposta e ceder, se imprescindível, uma parte dos seus direitos sobre castelos e cidades fronteiriças ao adversário. A paz, concebida por Mézières, compensaria as perdas sofridas:

"par vos deux personnes royalles Dieu entend a faire la reformacion de la Crestiente et l'exaltacion de la sainte vraye croix et de sa sainte foy catholique..." (54).

O prêmio maior era a posse da Terra Santa. Boa parte dos perturbadores dos reinos da França e Inglaterra morreriam no deserto aí criado pela guerra, como outrora morreram os ancestrais de Israel antes de alcançar a Terra Prometida. Carlos e Ricardo seriam então os novos Josué e Caleb a conduzir a Cristandade para Jerusalém. Haveria destino mais sublime?

"Lors pour l'amour de Dieu a yous deux roys vos deux royaumes vous sembleront de petit priz, voire au regart des empires et royaumes par la bonte (de) Dieu que vous conquesterez sur les ennemis de la foy" (55).

Aqui, porém, termina o otimismo do Velho Peregrino. Conhecedor dos homens e da política, sua experiência pregressa a serviço do rei de França, as peripécias do rei da Armênia para obter auxílio e os altos e baixos nas relações franco-inglesas ensinavam-no a moderar suas esperanças. Aliás, o Sonho tem um final melancólico: o autor prostrado ante o altar da igreja dos Celestinos desesperando-se por não conseguir a desejada paz.

Portanto, após as fagueiras perspectivas do capítulo 270 do livro terceiro, vemos a Verdade a aconselhar Carlos sobre a continuação da luta, caso fracassassem a paz ou as tréguas.

A possibilidade da continuação da querela é pois seriamente considerada, já que certos fatores continuavam a atuar, além mesmo das ambições pessoais e das pequenas divergências legais. Um deles, de ordem moral, era a abundância dos pecados dos franceses ou de seus inimigos, obrigando a

\footnotetext{
(53) - III, 270 (vol. 2, p. 375).

(54) - Idem, (vol. 2, p. 375).

(55) - Idem, (vol. 2, p. 377).
} 
Divina Providência a manter o castigo. Outro, de ordem política, era 0 prejuizo aos direitos e dignidade da Coroa da França.

No primeiro caso, a humilhação do rei e seu povo, a confissão sincera de suas faltas e a reparação das mesmas poderiam comutar a penalidade. Ao governante caberia então oferecer humildemente aos adversários um acordo de paz, dentro de suas possibilidades.

No segundo, todavia, as cousas se complicavam. Malgrado aceitar a renúncia a certos direitos e possessóes do reino, Filipe, com uma elevada idéia sobre a realeza, recuava ante qualquer concessão que ferisse mais a fundo os direitos da Coroa, da Igreja e dos súditos franceses. E não se tratava sequer de algo dependente da vontade do monarca, porque, aos olhos do autor, ele não tinha poderes para alienar aquilo que fosse de "la vraye essence, honneur et gloire ancienne de la couronne de France", da qual era apenas um ministro. A distinção entre a pessoa do rei e a Coroa, que vinha sendo lentamente elaborada no pensamento político do século XIV, criava destarte um impasse na solução do conflito, um non plus ultra, além do qual nenhuma concessão seria tolerada.

Dois desses pontos espinhosos eram a pretensão dos Plantagenetas ao trono francês e a questão da soberania sobre os territórios que mantinham no continente, sobretudo a Gasconha. No reinado de Ricardo esta última ocupava o primeiro plano. Desde o tratado de Paris, em 1259, que as tentativas de regularizar as diferenças entre o soberano francês e seu real vassalo inglês haviam fracassado diante do problema da soberania.

Em virtude da origem de seus direitos sobre a Aquitânia, os Plantagenetas pretendiam ter mão livre sobre o ducado, não reconhecendo o rei da França como o seu senhor eminente. Não lhe deviam nem homenagem nem fidelidade, e se Eduardo as prestara em 1325 e 29, o fizera devido a sua pouca idade e aos embustes dos ministros franceses, no dizer dos juristas ingleses. A reinvindicação e uso do título real francês por ele, a partir de 1337, foi possivelmente uma das saídas que encontrou para a questão. Como não resultou em nada de concreto, estavam os juristas a buscar novas soluções durante as tréguas de 1389.

Tais ameaças aos direitos e diginidade da Coroa não deixavam outra alternativa senão a luta, que passava assim a ser tão justa quanto a conduzida contra herejes ou infiéis (56).

Mézières estabelece cinco pontos a serem observados pelo rei na condução da guerra. Quatro dizem respeito às finanças e ao exército; mas o quinto é a conservação de uma permanente disposição para a paz. Se Carlos prevalecesse sobre os adversários e estes solicitasem tréguas ele deveria aceder. Seria perigoso continuar a contenda levado pela embriaguez do

(56) - III, 271 (vol. 2, p. 379). 
sucesso, pois Deus poderia transformá-lo em amargura (57). E, além disso, a paz ou tréguas eram necessárias para a realização da cruzada.

Sendo impossível fazê-la em conjunto com o rei inglês, Carlos deveria conduzir sozinho os exércitos cristãos à Terra Santa, para dar satisfação a Deus pelos pecados do povo e "pour esmouvoir aussi toute la Crestiente a ceste sainte besoingne". No fundo, era esta a grande esperança do autor, por isso ele dedicou duas partes do seu livro ao reino francês, mostrando as falhas aí existentes e ensinando a Carlos VI os remédios para saná-las. A partir do capítulo 283 da última parte ele dá conselhos sobre as disposições a serem tomadas antes da partida. A primeira, como já vimos, era o acerto de contas com a Inglaterra. O reino, afinal, precisava ficar garantido contra os inimigos externos e... também contra os internos. A França há muito sofria com as "relíquias não santas" deixadas pela guerra: os bandos de soldados licenciados. Era preciso livrar-se deles. Uns deveriam ser obrigados a trabalhar duramente para pagar por seus erros; outros, os melhores, integrariam os exércitos da Terra Santa (58).

Como vemos, nosso autor, à medida em que avança em suas reflexões, reduz a magnitude de seus projetos. Da cruzada conjunta ele passa ao empreendimento singular, a ser levado a cabo pelo rei da França. Porém, para qualquer das possibilidades, a guerra constituía um magno obstáculo. Para removê-lo necessário se fazia eliminar as causas que a alimentavm.

Causas morais: os pecadores dos franceses. Os cinqüenta anos de flagelo teriam sido castigo suficiente? Filipe não estava bem certo. $\mathrm{E}$ verdade que os meirinhos divinos se haviam excedido em conquistas e crueldade. Mas, quem poderia desvendar os desígnios ocultos da Providência Divina?

No momento, a juventude e a pureza de coração de ambos monarcas representavam um bom penhor de salvação. Suas mãos inocentes e sua boa vontade poderiam atrair a misericórdia divina e alcançar uma solução final para a contenda.

Porém, qual solução? As reflexões acerca desta lançam novamente o problema para a realidade política. As impertinências legais dos mediadores poderiam ser evitadas, com o encontro pessoal dos soberanos. Pequenas renúncias poderiam ser feitas. Mas, quando se esbarrava naquelas cousas pertinentes à soberania territorial e aos direitos e prerrogativas da Coroa, a questão se mostrava quase insolúvel.

Insolúvel e importante - no Sonho do Velho Peregrino ela aparece, como obstáculo, ao mesmo nível da cruzada. Sua solução, mas dentro dos

(57) - Idem, (vol. 2, p. 380).

(58) - III, 284 (vol. 2, p. 431). 
limites viáveis, era uma condição sine qua non para o término da guerra e, conseqüentemente, para a realização do santo empreendimento. Que não era possível liquidar o conflito com prejuízo para a integridade da Coroa, mesmo estando em jogo uma causa santa, o autor o deixa bem claro no capítulo 270 do terceiro livro.

Portanto a verdadeira oposição aos projetos cruzadísticos não vinha dos ingleses, nem de suas guerras. Ela se originava antes no nível mais profundo do nacionalismo emergente, que se refletia na própria Guerra dos Cem Anos. A cruzada contra 0 infiel opunha a Cristandade a um outro mundo, e a premissa básica para sua existência seria a coesão interna do orbe cristão. Ora, já desde o século XIII que esta vinha sendo rompida pelo desenvolvimento do particularismo, não mais em escala local ou regional - facilmente superável —, mas em escala nacional. Aos interesses gerais da Cristandade se contrapunham os interesses dos reinos, que, sendo mais próximos, prevaleciam. O fenômeno é bastante conhecido dos historiadores, que nele veem o mais sério óbice, quiçá, à continuidade das cruzadas no final da Idade Média. Sua manifestação junto a um autor tão imbuído do ideal cristão da cruzada como Mézières revela bem a força de tais interesses.

Filipe não constituía pois exceção entre os contemporâneos. Os franceses justificavam a guerra com o ser defensiva; mas os ingleses avocavam o mesmo argumento, pois encaravam os Valois como usurpadores. Minot, Langland, Gower, entre outros autores ingleses, são unânimes em considerar legítima a causa de seus soberanos. $E$, inclusive, nem sempre eram favoráveis à idéia de concessões aventada por Mézières. O tratado de Brétigny, por exemplo, recebera críticas até de um pacifista como Langland (59).

No entanto esses autores também conservavam o ideal de cruzada; muito embora com dúvidas, por vezes, sobre a legitimidade da matança de infiéis. Por outro lado a cruzada oferecia aspectos práticos, como o de válvula de escape para elementos indesejáveis no reino. Filipe pretendia empregar aí as companhias de mercenários que erravam pelo território francês. Outra não parece ter sido também a intenção de João-o-Bom, com o tomar a cruz em 1362. Já, na Inglaterra de Eduardo II, um poeta anônimo, descontente com as dissensões promovidas pela aristocracia, propunha a esta descarregar suas energias contra os infiéis (60).

Mas, até que ponto o ideal da reconquista da Terra Santa foi levado a sério no final do século XIV? Os papas continuavam interessados, tendo feito projetos para uma empresa conjunta dos monarcas europeus nos anos

(59) - Texto C, IV, 11. 241-48 (ed. do rev. Skeat, W.).

(60) - Poema intitulado Simonia, ed. por Wright, Th. in Political Songs of England, Londres, Camden Society, 1839. 
trinta (61). O cisma pontificial na segunda metade dese século desviou, no entanto, suas atenções: nosso autor preocupa-se também com mais este embaraço, no Sonho e em outras obras. Expedições individuais continuaram a ser efetivadas por nobres ocidentais, da França, Inglaterra e outros países. Nas décadas finais do século, mais precisamente entre 1384 e 1395, nasceu e tomou consistência o projeto de uma cruzada conjunta dos reis de França e Inglaterra, influenciando bastante as relações entre os dois reinos. Quem nos chama atenção sobre esse ponto é o historiador J.N.N. Palmer na obra já mencionada por nós. Aí ele estuda os altos e baixos da evolução desse plano, seu aspecto prático, seu aspecto idealístico e as pessoas envolvidas. Entre estas ele situa Filipe de Mézières que, apesar do retiro, continuava a aconselhar o soberano francês e a acompanhar atentamente o. rumo das negociações.

Assim ele deve tê-las certamente influenciado, pelo menos no tocante à cruzada. Já sobre outros aspectos das negociações é mais difícil afirmar qualquer cousa. De um modo geral, a direção que as propostas tomaram entre 1389 e 95 concorda com as idéias expostas no Sonho do Velho Peregrino. Por exemplo, em relação às concessões a serem feitas em prol da paz, sabemos que as delegações que negociaram em 1391 e 93 vieram armadas com substanciais ofertas, tanto de um, como de outro lado. Segundo Palmer, neste último ano os franceses fizeram as mais generosas concessões territoriais, desde o tratado de Paris em 1259 (62). Os ingleses não ficaram atrás, encontrando uma fórmula mais satisfatória para contornar o delicado problema da soberania sobre a Gasconha. O ducado passaria para João de Gaunt, que prestaria a homenagem em lugar do rei. O acordo seria coroado com o encontro dos monarcas (o desejo de Filipe), que então trataria do único ponto ainda em litígio: a natureza da possessão de Calais pelos ingleses.

As negociações seguiram portanto, em linhas gerais, as diretrizes preconizadas no Sonho do Velho Peregrino. Em princípios de 1395 Carlos VI dirigia uma missiva a seu colega inglês a respeito da cooperação mútua para o auxílio à Terra Santa e Filipe terminava a Epistre au Roy Richart.

Infelizmente a paz definitiva, como ele a desejava, fracassou; mas, logo no ano seguinte uma trégua de vinte e oito anos foi assinada em Paris. Era a outra alternativa prevista por nosso prático sonhador..

(61) - Cf. Alphandéry, P. La Chrétienté et l'idée de croisade, II. Paris, A. Michel, 1959, pp. 264-67.

(62) - Op. cit., p. 147. 